\title{
MOTIVATION-BASED IDENTITY OF ISLAND DESTINATIONS AND TOURIST SATISFACTION: THE CASE OF CROATIA ${ }^{1}$
}

\author{
Antonia Škravan \\ Lorena Bašan \\ Jelena Kapeš \\ Ivana Prižmić \\ Marino Franulović
}

https://doi.org//10.20867/tosee.06.50

\begin{abstract}
Purpose - This study focuses on common identity attributes of Croatian island destinations based on pull travel motivators. Its main purpose is to determine the significance of the gaps between the importance and performance of these attributes, as well as to examine their influence on overall satisfaction and destination brand loyalty.

Methodology - The survey was conducted in Croatia in 2020, using two interrelated questionnaires designed for two target groups, domestic tourists and Destination Marketing Organization (DMO) managers. A total of 116 valid questionnaires were collected from tourists and 6, from the DMOs of all coastal counties. Importance-performance analysis (IPA) was applied, followed by a paired sample t-test and simple linear regression analysis.

Findings - The IPA results show a negative and statistically significant difference between the importance and performance of natural and cultural attributes, making them the key points of future interest for DMO managers. The regression analysis results show a statistically significant and positive influence of all island destination attributes on overall satisfaction, and the significant positive influence of satisfaction on destination brand loyalty.

Contribution - The research provides evidence on satisfaction and loyalty concerning the main motivation-based identity attributes of island destinations. The results can help DMO managers to reallocate marketing efforts from low- to high-impact areas to achieve satisfaction and brand loyalty. The findings can also help reinforce the collaborative marketing activities of Croatian island destinations based on common identity attributes.
\end{abstract}

Keywords: motivation-based identity, identity attributes, tourist satisfaction, destination loyalty, island destination.

\section{INTRODUCTION}

With the faster development of tourism and increased competitiveness in the tourism market, there is a growing need for tourist destination branding. Similar to the general knowledge on brands, destination brands also have two important functions, identification and differentiation. (Qu, Kim and Im 2011). Branding highlights the

\footnotetext{
${ }^{1}$ This paper presents the research results on the student scientific-research project "Positioning Adriatic islands through online marketing activities", at the Faculty of Tourism and Hospitality Management, Opatija, Croatia, under mentorship of Lorena Bašan, PhD, Full Professor, realized in the academic year 2019/2020.
} 
ToSEE - Tourism in Southern and Eastern Europe, Vol. 6, pp. 757-773, 2021.

A. Škravan, L. Bašan, J. Kapeš, I. Prižmić, M. Franulović: MOTIVATION-BASED IDENTITY OF ...

diversity of a destination relative to competing destinations and helps to attract potential tourists to the destination (Blain 2005). It can be defined as a way to create and communicate a unique identity which is meaningful to visitors and investors, and to differentiate it from those adopted by competitors (Qu, Kim and Im 2011). Therefore, to build a strong brand, a clear and desirable identity is required (Lean, Pearson and Cai 2010). Although there is a thin thread linking the definitions of brand and brand identity, brand identity (Aaker and Joachimsthaler 2000) is simply what the organization wants its brand to mean. According to Pike (2012), brand identity, together with brand positioning and brand image, is the core construct in the destination branding process. Basically, brand identity development represents activities performed by destination marketing experts in identifying the desired image to be projected in the market. When identity is established, brand positioning is the next step in the process, where activities are performed according to what is envisioned in the brand identity. The third component, the image, is the real image that consumers have, which is usually influenced by the process of brand positioning and other sources such as social media and blogs. (Yusof and Ismail 2014). Therefore, if a destination's brand identity is strong, well understood and experienced by tourists, it will help to differentiate the destination from others (Shen-Hsihung, Chan-Hua, Yu-Ting 2016), by making it unique and unforgettable (Barišić, Prebezac and Mikulić 2012). However, research on destination brand identity is still lacking and there is an ongoing debate about its attributes (Shen-Hsihung, ChanHua, Yu-Ting 2016).

Destination attributes have been recognized as an important element of destination identity (Saraniemi and Komppula 2017) and they have been the subject of research in many studies to date (Alegre and Cladera, 2006; Djeri, Stamenković, Blešić, Miličević and Ivkov 2018; Kozak and Rimmington 2000; Ragavan et al. 2014). The utmost goal of tourist destinations is to achieve tourist satisfaction (Zhan et al. 2018) and, in order to assess overall satisfaction, the importance of and satisfaction with each component of a destination should be evaluated (Gursoy, Chen and Chi 2014). Tourist satisfaction is one of the main antecedents of destination loyalty, which appears as one of the outstanding trends in destination branding research (Ruiz-Real, Uribe-Toril and Gasquez-Abad 2020). Although the relationship between destination attributes, satisfaction, and loyalty is well documented in the tourism literature, this study considers the destination identity attributes based on pull motivation that, according to the push - pull motivational theory, refers to the destination offering (Prebensen et al. 2013). According to Yoon and Uysal (2005), the success of a destination should be guided by the analysis of tourist motivation and its relationship with satisfaction and loyalty. The motivation represents the first step in the travel decision-making process (Chi 2011) and pull motivators are considered to be one of the most critical determinants of tourist destination choice (Prebensen et al. 2013). According to Saraniemi and Komppula (2017), destination attributes, such as environment, culture, infrastructure, and attractions, are the core of destination brand identity, while at the same time representing important pull travel motivators.

This study therefore focuses on the common identity attributes of Croatian island destinations based on pull travel motivators. Croatia boasts more than 1200 islands, islets, reefs, and cliffs, occupying $69 \%$ of the Croatian coastline and $5 \%$ of the overall Croatian land territory (Razović and Tomljenović 2015). Thus, Croatian islands have exceptional tourism potential, especially given the growing trend of nature-based 
ToSEE - Tourism in Southern and Eastern Europe, Vol. 6, pp. 757-773, 2021.

A. Škravan, L. Bašan, J. Kapeš, I. Prižmić, M. Franulović: MOTIVATION-BASED IDENTITY OF ...

holidays at remote and unspoiled places such as small islands (Razović and Tomljenović 2015).

This paper aims to determine the significance of the gaps between the importance and perceived performance of three main groups of motivation-based destination identity attributes: (1) nature, (2) culture and gastronomy, and (3) outdoor and wellness facilities. Additionally, the research compares the tourists' perception of the attributes' importance in destination choice with the Destination Marketing Organization (DMO) managers' perception of the attributes' importance in destination identity creation, to identify the gap between them as well as the needed improvements. The paper's primary purpose is to examine the influence of motivation-based destination identity attributes on overall satisfaction with the island destination. Consequently, it examines the influence of overall satisfaction on island destination brand loyalty. In addition to providing insight into the crucial destination identity attributes and their relation to satisfaction and loyalty, this research also provides a framework for the collaborative marketing activities of Croatian islands, considering their common identity attributes based on travel motivation.

The paper is structured in five main sections. The introduction is followed by a literature review where the theoretical background is presented, and hypotheses, developed. In the third section, the research methodology is explained. The fourth section includes the research results and their discussion. Finally, the last section concludes with some recommendations for future researchers and destination marketing practitioners.

\section{LITERATURE REVIEW}

\subsection{Destination identity attributes and tourist motivation}

The extant literature on destination management recognizes destination brand identity as a crucial element of destination branding (Lean, Pearson and Cai 2010). As Wheeler $(2012,58)$ states, a brand identity is a strategic tool and an asset that provides quality reporting, increased recognition, and competitive differences. Its development is crucial because it represents the brand from the supply perspective (Yusof and Ismail 2016). Based on Aaker's (1996, as cited in Shen-Hsihung, Chan-Hua, Yu-Ting 2016, 1312) conceptualization, destination brand identity refers to a unique set of destination brand associations that tourists or stakeholders can use to identify and differentiate a destination brand from competitors. Therefore, it can be seen as the desired image that is sought to be achieved in the tourism market.

As Saraniemi (2010) pointed out, there are several perspectives when it comes to analyzing destination brand identity. However, there is still no consensus as to what constitutes a destination brand identity since the research is very limited (Shen-Hsihung, Chan-Hua, Yu-Ting 2016). Kapferer (1992) developed an analytical instrument known as Kapferer's Brand-Identity Prism. Three elements of the prism make up the tangible aspect of the destination (physique, relationship, and reflection), and the other three elements, the intangible aspect of the destination (personality, culture, and self-image). Konecnik and Go (2008) explored the concept of destination brand identity from the 
ToSEE - Tourism in Southern and Eastern Europe, Vol. 6, pp. 757-773, 2021.

A. Škravan, L. Bašan, J. Kapeš, I. Prižmić, M. Franulović: MOTIVATION-BASED IDENTITY OF ...

supply-side perspective, using the strategic brand analysis framework, consisting of three parts: tourist analysis, competitor analysis, and self-analysis. The problem of creating a brand identity is due to the complex destination product that includes a large number of specific products and services (Balmer and Greyser 2006).

According to Saraniemi and Komppula's (2017) recent research, the core of destination brand identity is culture, environment, infrastructure, and attractions. These attributes also act as main motivators that attract tourists to a destination (Katsikari et al. 2020). Tourism literature abounds in research on travel motivation (Prebensen et al. 2012). Since it usually represents the first step in the travel decision-making process (Chi 2011), travel motivation has aroused the interest of many researchers. One of the most common theories to study reasons why people travel is the push-pull theory (Gavcar and Gursoy 2002; Mohammad and Som 2010). According to this theory, people are pushed by some internal, psychological and emotional forces, while at the same time, they are pulled by external, situational and cognitive forces (Yoon and Uysal 2003; Ermawatti and Prihandono 2018; Mohammad and Som 2010). Thus, push motivation reflects what people are looking for in the travel experience (Prebensen et al. 2013), such as rest and relaxation, prestige, desire to escape, excitement and adventure. (Ermawatti and Prihandono 2018). Pull motivation is, on the contrary, based on destination attractiveness and how it is perceived by travelers (Mohammad and Som 2010). It represents motivation based on the aforementioned destination attributes such as natural scenery, beaches, cultural attractions, shopping, and recreation facilities (Yoon and Uysal 2003; Ermawatti and Prihandono 2018). According to Yoon and Uysal (2003), these destination attributes also may stimulate push motivations.

Due to the crucial role of destination attributes in attracting and retaining tourists, they often appear as the subject of research. Although destinations widely differ in terms of their characteristics and tourism offerings, some key attributes can be distinguished, such as nature, culture, gastronomy, or recreational facilities (Alegre and Cladera 2006; Chi and Qu 2008; Djeri, Stamenković, Blešić, Miličević and Ivkov 2018; Kozak and Rimmington 2000; Ragavan et al. 2014). Carvache-Francco et al. (2020) have focused their research on coastal destinations. According to their extensive literature review, the most common pull motivators that appear for coastal destinations are nature, cultural heritage, beaches, and sports. When observing Croatian coastal destinations, similar destination attributes appear to be the most important tourist motivators, namely sea and nature, cities and culture, and sports and recreation (TOMAS, 2019). Accordingly, the following hypotheses are proposed:

H1: There is a statistically significant difference between the perceived quality of island destinations' natural attributes and their importance in the destination selection process.

$H 2$ : There is a statistically significant difference between the perceived quality of island destinations' cultural attributes and their importance in the destination selection process.

H3: There is a statistically significant difference between the perceived quality of island destinations' outdoor and health attributes and their importance in the destination selection process. 
ToSEE - Tourism in Southern and Eastern Europe, Vol. 6, pp. 757-773, 2021.

A. Škravan, L. Bašan, J. Kapeš, I. Prižmić, M. Franulović: MOTIVATION-BASED IDENTITY OF ...

Improving the performance of destination attributes, thereby enhancing tourist satisfaction is one of the main functions of DMOs (Dmitrovic et al. 2009); however, the literature is often focused only on destination resources evaluation while neglecting the management activities (Dwyer et al. 2016). When tourist services are evaluated, it is important to assess them from both perspectives to understand whether the tourist perception of quality is consistent with the quality provided (Ciunova-Shuleska, Palamidovska and Griskih 2013). Based on this, the following is hypothesized:

H4: There is a statistically significant difference between attributes' importance in the destination selection process and their frequency of use in creating an island destination identity.

\subsection{Tourist satisfaction and destination loyalty}

Tourist satisfaction has been one of the main concerns of destination managers and tourism researchers for several decades. Extensive research on this subject gave rise to many definitions of tourist satisfaction; however, they mostly derive from the expectancy-disconfirmation theory proposed by Oliver (1980). According to the theory, tourist expectations represent standards by which tourists evaluate tourism services or destinations. When there is a gap between expectations and the perception of received service, disconfirmation is present, resulting in satisfaction or dissatisfaction (Do Valle, Silva, Mendes and Guerreiro 2006; Eusebio and Vieira 2011; Yuskel and Yuskel 2001). Therefore, tourist satisfaction can be defined as the overall post-visit evaluation of tourists compared to their pre-visit expectations (Asmelash and Kumaar 2019; Gnanapal 2015; Kotler 1999 Kim, Suh and Hwang 2003). Achieving tourist satisfaction is the basic goal of any destination (Zhan et al. 2018) since it has been proven that it positively affects word of mouth (Prebensen, Skallerud and Chen 2010; Wang, Tran and Tran 2017), revisit intention (Alegre and Garau 2010; Kozak and Rimmington 2000), and, ultimately, leads to loyalty (Chi and Qu 2008; Eusebio and Vieira 2011; Rahim, Ignatius and Adeoti 2012; Rajes 2013; Yoon and Uysal 2005). Despite the numerous positive effects of tourist satisfaction, its measurement still represents a challenge for researchers. Tourist satisfaction is a complex concept influenced by various factors, such as service quality, perceived value, or image; however, there is still an ongoing debate about its antecedents (Adinegara et al. 2018). Due to its multidimensionality (Yoon and Uysal 2005), tourist satisfaction has been often observed as the accumulated perception of various destination attributes and characteristics (Ragavan, Subramonian and Sharif 2014; Wang et al. 2009). Hence, the evaluation of destination attributes has become the key part of tourist satisfaction assessment. The influence of these attributes on tourist satisfaction has been confirmed by various authors (Chi and Qu 2008; Devesa, Laguna and Palacios 2010; Yoon and Uysal 2005). On the other hand, when observing studies on motivation, the pull motivators' influence on satisfaction appears to be unclear, as some researchers have confirmed that pull motivators positively influence satisfaction (Ermawatti and Prihandono 2018), while others did not find significant influences (Chindaprasert, Yasothornsrikul and Esichaikul 2015). However, this study observes the aforementioned destination identity attributes derived from pull motivators, rather than motivation itself. Therefore, based on the findings that the performance of destination attributes influences overall satisfaction, the following hypotheses are proposed: 
ToSEE - Tourism in Southern and Eastern Europe, Vol. 6, pp. 757-773, 2021.

A. Škravan, L. Bašan, J. Kapeš, I. Prižmić, M. Franulović: MOTIVATION-BASED IDENTITY OF ...

H5: Natural attributes of island destinations significantly influence overall satisfaction with a destination.

H6: Cultural attributes of island destinations significantly influence overall satisfaction with a destination.

H7: Outdoor and health attributes of island destinations significantly influence overall satisfaction with a destination.

As stated earlier, one of the concepts most commonly associated with satisfaction is loyalty. Their connection is well-established in the marketing literature (Bowen and Chen 2001; Dmitrović et al. 2009). As Bowen and Chen (2001) explain, although loyalty is difficult to define and operationalize, it is generally measured using three approaches: (1) the behavioral approach that refers to repetitive purchases, (2) the attitudinal approach that reflects customers' sense of loyalty, and (3) the composite approach that combines the first two dimensions of measurement. Accordingly, in a tourism context, destination loyalty manifests itself as tourists' intention to revisit the same destination, their favourable attitudes, intention to recommend the destination to others (Adinegara et al. 2018), and willingness to pay more for the service in the destination (Godovikh and Tasci 2020). Moreover, previous research shows that loyal customers are willing to pay 20 to 25 percent more for their product (Almeyda-Ibáñez, and George 2017). Given the positive outcomes of loyalty that result in economic benefits, achieving repeat visits through destination satisfaction is the goal that all destinations strive for. Based on the previous finding that confirmed the relationship between satisfaction and loyalty (Baker and Crompton 2000; Eusebio and Vieira 2011; Rahim, Ignatius and Adeoti 2012; Rajes 2013; Yoon and Uysal 2005), the following hypothesis is proposed:

H8: There is a significant influence of overall satisfaction on tourists' loyalty to island destination brands.

\section{METHODOLOGY}

Empirical research was conducted using the survey method on two separate and interrelated surveys. Structured questionnaires were applied. The research instruments were defined based on a literature review (Nadoo, Ramseook-Munhurrun and Durbarry 2012, Chen, Chen and Lee 2010 and Bakator, Đorđević and Ćoćkalo 2018) and on the analysis of island destination attractions, arranged in three groups of pull travel motivators: nature; culture and gastronomy; and outdoors and health.

The first questionnaire targeted domestic tourists within the context of choosing a destination. This survey aimed to identify priority attributes in each of the three groups of motivation-based destination identity attributes: 1) nature (10 items), 2) culture and gastronomy (16 items), 3) outdoors and health (15 items). Therefore, ImportancePerformance Analysis (IPA) was chosen as an excellent guide for allocating limited financial resources of companies and directing their actions toward the development of the attributes that have the highest value for the consumer (Djeri et al. 2018). The significance of the gaps was tested using a Paired-Sample t-Test. The research instruments consisted of three parts. The first part included six items relating to loyalty to Croatian island destinations and four items measuring overall satisfaction. 
ToSEE - Tourism in Southern and Eastern Europe, Vol. 6, pp. 757-773, 2021.

A. Škravan, L. Bašan, J. Kapeš, I. Prižmić, M. Franulović: MOTIVATION-BASED IDENTITY OF ...

Respondents were asked to indicate how much they agree or disagree with the statement, using a 5-point Likert scale (ranging from $1=$ strongly disagree to $5=$ strongly agree). The second part consisted of two questions related to island attributes' importance and perceived performance grouped into three pull travel motivators: 1) nature, 2) culture and gastronomy, and 3) outdoors and health. The respondents were asked to indicate on a 5-point scale (1-not important at all to 5-extremely important) the importance of each attribute to select an island destination. The perceived performances of island attributes were evaluated on a 5-point scale (1-poor to 5-excellent). The questions in the last part captured the socio-demographic characteristics of the respondents (gender, age, working experience, and the number of visits to Croatian island destinations). The questionnaire was created in Google forms and conducted as an online survey during May 2020 through Facebook and Whatsapp. A total of 116 questionnaires were collected and included in the analysis.

The second questionnaire was used to survey six coastal county DMOs. The survey was conducted from May 7, 2020, until June 3, 2020. The purpose was to compare the tourists' perception of the importance of island attributes in choosing a destination with the DMO managers' perception of the importance of attributes in creating an island identity and identifying what improvements need to be made. The questionnaire consisted of two parts. In the first part, the respondents were asked to indicate the importance of island attributes based on the frequency of using the motivation-based island identity attributes: 1) nature (10 items), 2) culture and gastronomy (16 items), and 3 ) outdoors and health (15 items). In the second part, respondents were asked to indicate the extent of use for each attribute in these three groups, using a 5-point scale (ranging from $1=$ never to $5=$ always). The questionnaire was created in Google forms and conducted online by sending links to the e-mail addresses of six coastal county DMOs.

Data analysis was carried out using the statistical software SPSS 23. ImportancePerformance Analysis (IPA), Paired-Sample t-test, Independent Sample t-test, Simple regression analysis, and descriptive statistics were implemented in data analysis.

\section{RESEARCH RESULTS AND DISCUSSION}

\subsection{Socio-demographic characteristics of respondents}

The gender structure of respondents shows there are more females $(81.9 \%)$ than males $(18.1 \%)$. The majority of respondents are between 18 and 24 years of age $(52.6 \%)$; while respondents aged $25-34$ account for $24.1 \%$; respondents aged $35-44$, for $18.1 \%$; respondents aged $45-54$, for $4.3 \%$, and respondents aged $55-64$, for $0.9 \%$. There were no respondents older than 65 .

Almost one half of the respondents hold a college degree $(45.7 \%)$, and $27.6 \%$ have a high school degree, followed by respondents with a university degree or higher $(26.7 \%)$. When asked about working experience, $62.9 \%$ of the respondents have less than five years of working experience; $15.5 \%$ have $6-10$ years; $12.9 \%$ have $11-20$ years; $7.8 \%$ have $21-30$ years; and $0.9 \%$ of the respondents have more than 31 years of working experience. 
ToSEE - Tourism in Southern and Eastern Europe, Vol. 6, pp. 757-773, 2021.

A. Škravan, L. Bašan, J. Kapeš, I. Prižmić, M. Franulović: MOTIVATION-BASED IDENTITY OF ...

\subsection{IPA and attribute reliability analysis}

The used research instruments and attributes were examined. Cronbach's alpha coefficients were used to test the internal consistency of attributes researched as pull travel motivators for island destination choice. (Table 1)

Table 1: Attribute reliability - island destination choice

\begin{tabular}{clcc}
\hline \multirow{2}{*}{ No. } & \multirow{2}{*}{$\begin{array}{l}\text { Dimensions related to island } \\
\text { destination choice }\end{array}$} & Importance & Cronbach's alpha \\
\cline { 3 - 4 } & & $(\mathrm{I})$ & Performance \\
\hline 1. & Nature & 0.872 & 0.901 \\
2. & Culture and gastronomy & 0.918 & 0.945 \\
3. & Outdoors and health & 0.886 & 0.942 \\
\hline
\end{tabular}

Source: authors' calculations

Table 1 shows three dimensions of pull travel motivators for the selection of an island destination by tourists. Cronbach's alpha for all three groups of motivation-based island attributes is higher than 0.7, recommended as the minimum level (Hair, Black, Babin and Anderson 2014).

Descriptive statistics were used to determine the importance and perceived performance of the three main groups of motivation-based island destination attributes. The following Paired Sample t-Test was used to determine the significance of differences between the importance of island attributes and the perceived quality of each attribute. In addition, gap analysis was performed between importance and perceived performance (Table 2)

Table 2: Importance - Performance scores

\begin{tabular}{|c|c|c|c|c|c|}
\hline \multirow[b]{2}{*}{ Attributes } & \multicolumn{5}{|c|}{ Nature } \\
\hline & $\begin{array}{l}\text { Importance } \\
\text { (I) }\end{array}$ & $\begin{array}{l}\text { Performance } \\
\text { (P) }\end{array}$ & $\begin{array}{l}\text { GAP } \\
(\mathrm{P}-\mathrm{I})\end{array}$ & $\mathrm{t}$ & $\begin{array}{c}\text { Sig. } \\
(2- \\
\text { tailed) }\end{array}$ \\
\hline The beauty of landscape & 4.63 & 4.48 & -0.15 & 2.213 & .029 \\
\hline Preserved environment & 4.61 & 4.16 & -0.45 & 5.731 & .000 \\
\hline Clean sea & 4.80 & 4.44 & -0.36 & 5.363 & .000 \\
\hline Clean beaches & 4.79 & 4.13 & -0.66 & 8.178 & .000 \\
\hline Clean environment & 4.73 & 4.05 & -0.68 & 8.148 & .000 \\
\hline $\begin{array}{l}\text { Cleanliness of the public } \\
\text { places and streets }\end{array}$ & 4.47 & 3.92 & -0.55 & 6.350 & .000 \\
\hline Climate in the destination & 4.03 & 4.17 & 0.14 & -1.480 & .141 \\
\hline Authenticity & 4.15 & 4.17 & 0.02 & -.341 & .734 \\
\hline Flora & 4.11 & 4.10 & -0.01 & .112 & .911 \\
\hline Fauna & 4.03 & 4.09 & 0.06 & -.661 & .510 \\
\hline Total & 4.44 & 4.17 & -0.27 & 4.801 & .000 \\
\hline
\end{tabular}


ToSEE - Tourism in Southern and Eastern Europe, Vol. 6, pp. 757-773, 2021.

A. Škravan, L. Bašan, J. Kapeš, I. Prižmić, M. Franulović: MOTIVATION-BASED IDENTITY OF ...

Table 2 (continued)

\begin{tabular}{|c|c|c|c|c|c|}
\hline Attributes & $\begin{array}{l}\text { Importance } \\
\text { (I) }\end{array}$ & $\begin{array}{l}\text { Performance } \\
\text { (P) }\end{array}$ & $\begin{array}{l}\text { GAP } \\
(\mathrm{P}-\mathrm{I})\end{array}$ & $\mathrm{t}$ & $\begin{array}{c}\text { Sig. } \\
(2- \\
\text { tailed) }\end{array}$ \\
\hline & \multicolumn{5}{|c|}{ Culture and gastronomy } \\
\hline $\begin{array}{l}\text { Monumental and cultural } \\
\text { heritage }\end{array}$ & 3.86 & 3.63 & -0.23 & 2.532 & .013 \\
\hline $\begin{array}{l}\text { Remains of historical } \\
\text { fortifications }\end{array}$ & 3.78 & 3.53 & -0.25 & 2.415 & .017 \\
\hline Archaeological sites & 3.50 & 3.28 & -0.22 & 2.156 & .033 \\
\hline Collections of objects & 3.10 & 3.09 & -0.01 & .155 & .877 \\
\hline $\begin{array}{l}\text { Famous churches and } \\
\text { monasteries }\end{array}$ & 3.61 & 3.62 & 0.01 & -.088 & .930 \\
\hline Folklore creations & 3.09 & 3.38 & 0.29 & -2.394 & .018 \\
\hline Cultural-historical events & 3.63 & 3.54 & -0.09 & .821 & .413 \\
\hline Religious customs & 2.86 & 3.22 & 0.36 & -3.093 & .002 \\
\hline Traditional arts and craft & 3.68 & 3.66 & -0.02 & .242 & .810 \\
\hline Customs and way of life & 3.95 & 3.65 & -0.30 & 2.962 & .004 \\
\hline $\begin{array}{l}\text { Variety of restaurants and } \\
\text { other catering facilities }\end{array}$ & 4.09 & 3.81 & -0.28 & 3.266 & .001 \\
\hline Quality of food and beverages & 4.39 & 3.92 & -0.47 & 5.251 & .000 \\
\hline The authenticity of the dishes & 4.28 & 3.85 & -0.43 & 4.499 & .000 \\
\hline $\begin{array}{l}\text { Recognition of local } \\
\text { specialties }\end{array}$ & 4.28 & 3.92 & -0.36 & 4.251 & .000 \\
\hline Wine roads & 3.73 & 3.55 & -0.18 & 1.657 & .100 \\
\hline Olive oil roads & 3.81 & 3.47 & -0.34 & 3.071 & .003 \\
\hline \multirow[t]{2}{*}{ Total } & 3.73 & 3.57 & -0.16 & 2.385 & .019 \\
\hline & \multicolumn{5}{|c|}{ Outdoors and health } \\
\hline $\begin{array}{l}\text { Underwater observation and } \\
\text { research }\end{array}$ & 3.41 & 3.22 & -0.19 & 1.711 & 0.090 \\
\hline Diving & 3.16 & 3.21 & 0.05 & -.461 & 0.645 \\
\hline Sportfishing & 2.69 & 2.84 & 0.15 & -1.467 & 0.145 \\
\hline Walking paths & 4.04 & 3.78 & -0.26 & 2.405 & 0.018 \\
\hline Hiking trails & 3.66 & 3.51 & -0.15 & 1.312 & 0.192 \\
\hline Educational trails & 3.68 & 3.29 & -0.39 & 3.382 & 0.001 \\
\hline Cycling paths & 3.38 & 3.38 & 0.00 & .000 & 1.000 \\
\hline Entertainment opportunities & 3.78 & 3.67 & 0.11 & 0.861 & 0.391 \\
\hline $\begin{array}{l}\text { Facilities for families and } \\
\text { children }\end{array}$ & 3.61 & 3.61 & 0.00 & .000 & 1.000 \\
\hline Facilities for boaters & 2.66 & 3.11 & 0.45 & -3.706 & 0.000 \\
\hline Facilities of rural tourism & 3.41 & 3.25 & -0.16 & 1.403 & 0.163 \\
\hline $\begin{array}{l}\text { Facilities of health and } \\
\text { wellness tourism }\end{array}$ & 3.53 & 3.34 & -0.19 & 1.724 & 0.087 \\
\hline $\begin{array}{l}\text { Travel agencies' excursion } \\
\text { offering }\end{array}$ & 3.74 & 3.70 & -0.04 & .362 & 0.718 \\
\hline Shopping opportunities & 3.04 & 3.14 & 0.10 & .816 & 0.416 \\
\hline $\begin{array}{l}\text { Ecological products } \\
\text { shopping/consumption } \\
\text { opportunities }\end{array}$ & 3.68 & 3.68 & 0.00 & .000 & 1.000 \\
\hline Total & 3.43 & 3.38 & -0.05 & .731 & .466 \\
\hline
\end{tabular}

Source: authors' calculation 
ToSEE - Tourism in Southern and Eastern Europe, Vol. 6, pp. 757-773, 2021.

A. Škravan, L. Bašan, J. Kapeš, I. Prižmić, M. Franulović: MOTIVATION-BASED IDENTITY OF ...

The results presented in Table 2 indicate significant differences $(p<0.05)$ between the importance and the perceived quality of the "Nature" $(\mathrm{p}=0.000)$ and "Culture and gastronomy" ( $\mathrm{p}=0.019)$ pull travel motivators. In six out of ten observed attributes in the group of natural attributes, there are significant differences between the attributes' importance in selecting an island destination and the perceived quality of the island attributes. Since for the mayority of observed natural attributes there are significant differences, hypothesis (H1) is confirmed.

Eleven of the sixteen observed attributes in the "Culture and gastronomy" motivator group show a significant difference between the importance and the perceived quality of the islands' attributes. Thus, hypothesis (H2) is confirmed.

There are no significant differences between importance and perceived quality in the group of "Outdoors and health" motivators $(\mathrm{p}=0.466)$. In this group, there is a significant difference between importance and performance only for the attribute "Facilities for boaters". Following this, hypothesis (H3) is rejected.

\subsection{Independent Sample t-test for attribute importance}

The Independent Sample t-Test was implemented to assess differences between the importance of attributes for tourists in choosing an island destination and their importance for DMOs, seen from the frequency of use in creating island destination identity. Cronbach's alpha coefficients were used to test the reliability of attributes used as motivation-based island identity attributes. All values of Cronbach's alfa coefficients are above the required minimum of 0.7 (Table 3 ).

Table 3: Attribute reliability - creating island destination identity

\begin{tabular}{clc}
\hline No. & Dimensions related to creating island destination identity & Cronbach's alpha \\
\hline 1. & Nature & 0.842 \\
2. & Culture and gastronomy & 0.907 \\
3. & Outdoors and health & 0.859 \\
\hline
\end{tabular}

Source: authors' calculations

The results of the analysis are presented in Table 4 .

Table 4: Independent Sample t-Test (attributes' importance in choosing a destination choice and in creating island destination identity)

\begin{tabular}{lccrr}
\hline \multirow{2}{*}{$\begin{array}{l}\text { Dimensions related to choosing an } \\
\text { island destination and creating island } \\
\text { destination identity }\end{array}$} & \multicolumn{2}{c}{$\begin{array}{c}\text { Levene's Test for } \\
\text { Equality of variances }\end{array}$} & \multicolumn{2}{c}{$\begin{array}{c}\text { t-test for equality of } \\
\text { means }\end{array}$} \\
\cline { 2 - 5 } & $\mathrm{F}$ & Sig. & $\mathrm{t}$ & $\begin{array}{c}\text { Sig. } \\
(2-t a i l e d)\end{array}$ \\
\hline Nature & .392 & .533 & -.707 & .481 \\
Culture and gastronomy & 1.209 & .274 & -1.389 & .167 \\
Outdoors and health & .766 & .383 & -1.610 & .110 \\
\hline
\end{tabular}

Source: authors' calculation 
ToSEE - Tourism in Southern and Eastern Europe, Vol. 6, pp. 757-773, 2021.

A. Škravan, L. Bašan, J. Kapeš, I. Prižmić, M. Franulović: MOTIVATION-BASED IDENTITY OF ...

The results show that for all three researched constructs, there are no significant differences between the attributes' importance for tourists in choosing an island destination and their importance for DMOs in creating an island destination identity ( $p>0.05)$. Thus, it can be concluded that the importance of island attributes is aligned between tourists and DMO managers across all three groups of motivation-based island attributes. Based on the absence of significant differences between the importance of attributes for tourists and DMO managers, hypothesis (H4) is not confirmed.

For DMO managers and future guidelines for their operations, it is important to identify differences in a few factors in each dimension as a pull travel motivator. In the "Nature" dimension, there are significant differences between the importance which "Cleanliness of the public places and streets" $(\mathrm{p}=0.010)$ and "Authenticity" have for tourists and the importance they have for DMOs. In the "Culture and gastronomy" dimension, significant differences were noticed in "Folklore creations" $(\mathrm{p}=0.024)$. In the last dimension, "Outdoors and health," significant differences were determined for "Diving" $(\mathrm{p}=0.032)$, "Cycling path" ( $\mathrm{p}=0.023)$, and "Facilities for boaters" ( $\mathrm{p}=0.001)$. DMO managers need to focus their attention on these attributes and should seek to align the importance that these attributes have for tourists in choosing island destinations with the importance they have for DMO managers in creating island identities.

\subsection{Regression analysis of overall satisfaction and loyalty}

Regression analysis was performed to identify the influence of island attributes on tourists' overall satisfaction, and the influence of overall satisfaction on tourists' loyalty to the island destinations.

Overall satisfaction was measured with four items, for which the calculated Cronbach's alpha coefficient was above the requested minimum of 0.7 (Table 5).

Table 5: Overall satisfaction reliability

\begin{tabular}{clc}
\hline No. & \multicolumn{1}{c}{ Satisfaction items } & $\begin{array}{c}\text { Cronbach's } \\
\text { alpha }\end{array}$ \\
\hline 1. & Tourism products of the Croatian island brands satisfy my needs. & \\
2. & I am satisfied when I purchase Croatian island tourism products. & 0.951 \\
3. & $\begin{array}{l}\text { I feel good when I purchase Croatian island tourism products. } \\
\text { 4. }\end{array}$ & \\
& $\begin{array}{l}\text { I don't have regrets after purchasing Croatian island tourism } \\
\text { products. }\end{array}$ & \\
\hline
\end{tabular}

Source: authors' calculations

To examine the influences of island attributes on tourists' overall satisfaction, a Simple regression analysis was implemented. Following the three main groups of motivationbased island attributes, Simple regression analysis was chosen as an adequate method to evaluate separately for each group of motivation-based attributes influencing tourists' overall satisfaction. The results are presented in Table 6. 
ToSEE - Tourism in Southern and Eastern Europe, Vol. 6, pp. 757-773, 2021.

A. Škravan, L. Bašan, J. Kapeš, I. Prižmić, M. Franulović: MOTIVATION-BASED IDENTITY OF ...

Table 6: Simple regression analysis for attributes affecting overall satisfaction

\begin{tabular}{|c|c|c|c|c|c|}
\hline \multirow[t]{2}{*}{ Independent variable } & \multicolumn{5}{|c|}{ Overall satisfaction } \\
\hline & $\mathrm{B}$ & $\mathrm{SE}$ & BETA & $\mathrm{t}$ & Sig. \\
\hline Constant & 5.264 & 2.658 & & 1.981 & .050 \\
\hline Nature & .206 & .063 & .293 & 3.266 & .001 \\
\hline $\mathrm{R}^{2}$ & 0.086 & & & & \\
\hline Adjusted $\mathrm{R}^{2}$ & 0.078 & & & & \\
\hline Standard error & 3.728 & & & & \\
\hline F ratio & 10.667 & & & & \\
\hline Significance & 0.001 & & & & \\
\hline Constant & 9.131 & 1.645 & & 5.552 & .000 \\
\hline $\begin{array}{l}\text { Culture and } \\
\text { gastronomy }\end{array}$ & .083 & .028 & .266 & 2.949 & .004 \\
\hline $\mathrm{R}^{2}$ & 0.071 & & & & \\
\hline Adjusted $\mathrm{R}^{2}$ & 0.063 & & & & \\
\hline Standard error & 3.758 & & & & \\
\hline F ratio & 8.699 & & & & \\
\hline Significance & 0.004 & & & & \\
\hline Constant & 9.716 & 1.488 & & 6.531 & .000 \\
\hline Outdoors and health & .082 & .029 & .260 & 2.873 & .005 \\
\hline $\mathrm{R}^{2}$ & 0.068 & & & & \\
\hline Adjusted $\mathrm{R}^{2}$ & 0.059 & & & & \\
\hline Standard error & 3.765 & & & & \\
\hline$F$ ratio & 8.255 & & & & \\
\hline Significance & 0.005 & & & & \\
\hline
\end{tabular}

Source: authors' calculation

The significance value from Levene's Test $(\mathrm{p}<0.05)$ indicates that "Nature" attributes are significant $(\beta=.293, p=0.001)$ in estimating overall satisfaction and explain $8.6 \%$ variance of tourists' overall satisfaction, whose pull motivator to travel is nature $\left(\mathrm{R}^{2}=.086\right)$. Based on these results, hypothesis (H5) was confirmed.

"Culture and gastronomy" attributes have a significant influence on overall satisfaction $(\beta=.266, p=0.004)$ and explain $7.1 \%$ of overall satisfaction $\left(\mathrm{R}^{2}=.071\right)$. These results confirm hypothesis (H6).

Regarding the "Outdoors and health" attributes of island destinations, the value $\mathrm{p}=0.005$ indicates a significant influence of these attributes on overall tourist satisfaction. This group of attributes explains $6.8 \%$ of overall tourist satisfaction $\left(\mathrm{R}^{2}=.068\right)$. Thus, hypothesis $(\mathrm{H} 7)$ is confirmed.

These results are consistent with previous studies that found the positive influence of destination attributes on overall satisfaction (Chi and Qu 2008; Devesa, Laguna and Palacios 2010; Yoon and Uysal 2005).

Additionally, Simple regression analysis was performed to identify the influence of overall tourist satisfaction on tourist loyalty to island destinations in different groups of 
ToSEE - Tourism in Southern and Eastern Europe, Vol. 6, pp. 757-773, 2021.

A. Škravan, L. Bašan, J. Kapeš, I. Prižmić, M. Franulović: MOTIVATION-BASED IDENTITY OF ...

motivation-based attributes. For that purpose, the reliability of loyalty was calculated. Loyalty was measured with six items (Table 7), for which the value of Cronbach's alpha coefficient was above 0.7 .

\section{Table 7: Loyalty reliability}

\begin{tabular}{clc}
\hline No. & \multicolumn{1}{c}{ Loyalty items } & Cronbach's alpha \\
\hline 1. & I find myself loyal to the Croatian island brands. & \\
2. & I'm ready to pay more for these brands. & 0.916 \\
3. & Croatian island brands are my first choice. & \\
4. & I'm loyal only to the Croatian island brands. & \\
5. & I always buy these tourism product brands. & \\
6. & I usually buy these tourism product brands. & \\
\hline
\end{tabular}

Source: authors' calculations

The results of the influence of overall satisfaction on tourists' loyalty to island destinations are shown in Table 8.

Table 8: Simple regression analysis of overall satisfaction affecting loyalty

\begin{tabular}{lccccc}
\hline Independent variable & \multicolumn{5}{c}{ Loyalty } \\
\cline { 2 - 5 } & $\mathrm{B}$ & $\mathrm{SE}$ & $\mathrm{BETA}$ & $\mathrm{t}$ & Sig. \\
\hline Constant & 5.277 & 1.689 & & 3.162 & .002 \\
Overall satisfaction & .811 & .116 & .546 & 6.992 & .000 \\
\hline $\mathrm{R}^{2}$ & 0.298 & & & \\
Adjusted R & 0.292 & & & \\
Standard error & 4.826 & & & \\
F ratio & 48.892 & & & \\
Significance & 0.000 & & & \\
\hline
\end{tabular}

Source: authors' calculations

It is evident from the above results and the significance value of Levene's Test $(\mathrm{p}<0.05)$ that overall satisfaction is significant $(\beta=.546, \mathrm{p}=.000)$ in estimating tourists' loyalty to island destinations. Overall satisfaction explained a $29.8 \%$ variance in loyalty to the island destinations $\left(\mathrm{R}^{2}=.298\right)$, which confirms hypothesis $(\mathrm{H} 8)$. The finding supports the results of some previous studies that also found the positive and significant influence of overall satisfaction on destination loyalty (Eusebio and Vieira 2011; Rahim, Ignatius and Adeoti 2012; Rajes 2013; Yoon and Uysal 2005), thus confirming that satisfaction can be considered one of the crucial determinants of loyalty (Gursoy, Chen and Chi 2014). 
ToSEE - Tourism in Southern and Eastern Europe, Vol. 6, pp. 757-773, 2021.

A. Škravan, L. Bašan, J. Kapeš, I. Prižmić, M. Franulović: MOTIVATION-BASED IDENTITY OF ...

\section{CONCLUSION}

This research contributes to the body of knowledge by providing evidence on satisfaction and loyalty with regard to the main motivation-based identity attributes of island destinations. The practical implications for managers are derived from the study's contribution in providing information regarding crucial destination attributes. The results can help DMO managers to reallocate marketing efforts from low- to high-impact areas to achieve satisfaction and brand loyalty. The recommendations arising from the results can help reinforce the collaborative marketing activities of Croatian island destinations based on common identity attributes and yield more effective and efficient island promotion in the tourism market.

The research presented in this paper has some limitations. The gender structure of the respondents is uneven since most of them are female. The research was conducted during the Covid-19 pandemic, and for that reason, the sample is relatively small. For future research, it is suggested to expand the sample.

\section{REFERENCES}

Aaker, D. A. and Joachimsthaler, E. (2000), "The brand relationship spectrum: The key to the brand architecture challenge", California Management Review, Vol. 42, No. 4, pp. 8-23. doi: 10.1177/000812560004200401

Adinegara, J., Suprapti, N.W.S., Yasa, N.N.K. and Sukaatmadja, I. (2018), “Antecedents and consequences of tourist satisfaction: A literature review", ASEAN Marketing Journal, Vol. 9, No. 1, pp. 40-53. doi: 10.21002/amj.v9i2.5686

Alegre, J. and Cladera, M. (2006), "Repeat visitation in mature sun and sand holiday destinations", Journal of Travel Research, Vol. 44, No. 3, pp. 288-297.

Almeyda-Ibáñez, M. and George, B.P. (2017), "The evolution of destination branding: A review of branding literature in tourism", Journal of Tourism, Heritage \& Services Marketing, Vol. 3, No. 1, pp. 9-17. doi: 10.5281 /zenodo. 401370

Baker, D.A., and Crompton, J.L. (2000), "Quality, satisfaction and behavioral intentions". Annals of Tourism Research, Vol. 27, No. 3, pp. 785-804. doi: 10.1016/S0160-7383(99)00108-5

Balmer, J. M. and Greyser, S. A. (2006), "Corporate marketing: Integrating corporate identity, corporate branding, corporate communications, corporate image and corporate reputation", European Journal of Marketing, Vol. 40, No. 7/8, pp. 730-741. doi: 10.1108/03090560610669964

Barišić, P., Prebežac, D. and Mikulić, J. (2012), "The image and identity of Croatia as a tourist destination: An exploratory study", 6th International Conference An Enterprise Odyssey: Corporate governance and public policy-path to sustainable future, Šibenik, 13-16 June, 2012, pp. 1280-1290.

Blain, C., Levy, S.E. and Ritchie, J.B. (2005), "Destination branding: Insights and practices from destination management organizations". Journal of Travel Research, Vol. 43, No. 4, pp. 328-338. doi: $10.1177 / 0047287505274646$

Bowen, J.T. and Chen, S.L. (2001), "The relationship between customer loyalty and customer satisfaction", International Journal of Contemporary Hospitality Management, Vol. 13, No. 5, pp. 213-2017. doi: 10.1108/09596110110395893

Carvache-Franco, W., Carvache-Franco, M. and Hernández-Lara, A.B. (2020), "From motivation to segmentation in coastal and marine destinations: a study from the Galapagos Islands, Ecuador", Current Issues in Tourism, doi: 10.1080/13683500.2020.1811651

Chi, C.G.Q. and Qu, H. (2008), "Examining the structural relationships of destination image, tourist satisfaction and destination loyalty: An integrated approach", Tourism Management, Vol. 29, No. 4, pp. 624-636. doi: 10.1016/j.tourman.2007.06.007

Chindaprasert, K., Yasothornsrikul, P. and Esichaikul, R. (2015), "The Effects of Motivation and Satisfaction on Destination Loyalty at the Thailand -Laos (PDR) Border",. Asia-Pacific Journal of Innovation in Hospitality and Tourism, Vol. 4, No. 1, doi: 10.7603/s40930-015-0001-y 
ToSEE - Tourism in Southern and Eastern Europe, Vol. 6, pp. 757-773, 2021.

A. Škravan, L. Bašan, J. Kapeš, I. Prižmić, M. Franulović: MOTIVATION-BASED IDENTITY OF ...

Ciunova-Shuleska, A., Palamidovska, N. and Grishin, M. (2013), “An empirical assessment of service quality in the context of travel agenciesin the Republic of Macedonia", Market-Tržište, Vol. 25, No. 1, pp. 21-36.

Devesa, M., Laguna, M., and Palacios, A. (2010), "The role of motivation in visitor satisfaction: Empirical evidence in rural tourism", Tourism Management, Vol. 31, No. 4, pp. 547-552. doi: 10.1016/j.tourman.2009.06.006

Djeri, L., Stamenković, P., Blešić, I., Milićević, S. and Ivkov, M. (2018), “An importance-performance analysis of destination competitiveness factors: case of Jablanica district in Serbia", Economic ResearchEkonomska istraživanja, Vol. 31, No. 1, pp. 811-826. doi: 10.1080/1331677X.2018.1456351

Dmitrović, T., Cvelbar, L. K., Kolar, T., Brencic, M. M., Ograjenšek, I. and Žabkar, V. (2009), "Conceptualizing tourist satisfaction at the destination level", International Journal of Culture, Tourism and Hospitality Research, Vol. 3, No. 2, pp. 116-126. doi: 10.1108/17506180910962122

Do Valle, P.O., Silva, J.A., Mendes, J., and Guerreiro, M. (2006), Tourist satisfaction and destination loyalty intention: A structural and categorical analysis", International Journal of Business Science \& Applied Management, Vol. 1, No. 1, pp. 25-44.

Dwyer, L., Dragićević, V., Armenski, T., Mihalič, T. and Cvelbar, K.L. (2016), Achieving destination competitiveness: an importance-performance analysis of Serbia", Current Issues in Tourism, Vol. 19, No. 13, pp. 1309-1336. doi:10.1080/13683500.2014.944487

Ermawati, F. and Prihandono, D. (2018), “The Influence Of Destination Image, Push And Pull Travel Motivation Towards Tourist Loyalty Through Tourist Satisfaction", Management Analysis Journal, Vol. 7, No. 4, pp. 414-425. doi: 10.15294/MAJ.V7I4.23554

Eusébio, C., and Vieira, A.L. (2011), "Destination attributes' evaluation, satisfaction and behavioural intentions: A structural modelling approach", International Journal of Tourism Research, Vol. 15, No. 1, pp. 66-80. doi: 10.1002/jtr.877

Gavcar, E., and Gursoy, D. (2002), „Research note: An examination of destination-originated (pull) factors", Tourism Analysis, Vol, 7, No. 1, pp. 75-81. doi: 10.3727/108354202129687705

Godovykh, M. and Tasci, A.D. (2020), "The influence of post-visit emotions on destination loyalty", Tourism Review, Vol. 76, No. 1, pp. 277-288. doi: 10.1108/TR-01-2020-0025

Gursoy, D., Chen, J.S. and Chi, C.G. (2014), "Theoretical examination of destination loyalty formation", International Journal of Contemporary Hospitality Management, Vol. 26, No. 5, pp. 809-827. doi: 10.1108/IJCHM-12-2013-0539

Institut za turizam (2020), TOMAS Hrvatska 2019: Stavovi i potrošnja turista u Hrvatskoj, Zagreb: Institut za turizam.

Kapferer, J.N. (1992), Strategic brand management, Kogan Page, London.

Katsikari, C., Hatzithomas, L., Fotiadis, T. and Folinas, D. (2020), "Push and Pull Travel Motivation: Segmentation of the Greek Market for Social Media Marketing in Tourism”, Sustainability, Vol. 12, No. 11, pp. 4770. doi: 10.3390/su12114770

Konecnik, M. and Go, F. (2008), "Tourism destination brand identity: The case of Slovenia", Journal of Brand Management, Vol. 15, No. 3, pp. 177-189. doi: 10.1057/palgrave.bm.2550114

Kozak, M., and Rimmington, M. (2000), "Tourist satisfaction with Mallorca, Spain, as an off-season holiday destination", Journal of Travel Research, Vol. 38, No. 3, pp. 260-269. doi: $10.1177 / 004728750003800308$

Križman Pavlović, D., (2008), Marketing turističke destinacije, Sveučilište Jurja Dobrile u Puli, Pula.

Lin, Y.C., Pearson, T.E. and Cai, L.A. (2011), "Food as a form of destination identity: A tourism destination brand perspective", Tourism and Hospitality Research, Vol. 11, No. 1, pp. 30-48. doi: 10.1057/thr.2010.22

Mohammad, B.A.M.A.H. and Som, A.P.M. (2010), "An analysis of push and pull travel motivations of foreign tourists to Jordan", International Journal of Business and Management, Vol. 5, No. 12, pp. 41-50. doi: 10.5539/ijbm.v5n12p41

Pike, S. (2012), Destination marketing, Routledge, Oxford.

Prebensen, N.K., Woo, E., Chen, J.S. and Uysal, M. (2012), "Motivation and involvement as antecedents of the perceived value of the destination experience", Journal of Travel Research, Vol. 52, No. 2, pp. 253-264. doi: 10.1177/0047287512461181

Qu, H., Kim, L.H. and Im, H.H. (2011), “A model of destination branding: Integrating the concepts of the branding and destination image", Tourism Management, Vol. 32, No. 3, pp. 465-476. doi: 10.1016/j.tourman.2010.03.014

Ragavan, N.A., Subramonian, H. and Sharif, S.P. (2014). "Tourists' perceptions of destination travel attributes: An application to International tourists to Kuala Lumpur", Procedia-Social and Behavioral Sciences, Vol. 144, No. 20, pp. 403-411. doi: doi.org/10.1016/j.sbspro.2014.07.309 
ToSEE - Tourism in Southern and Eastern Europe, Vol. 6, pp. 757-773, 2021.

A. Škravan, L. Bašan, J. Kapeš, I. Prižmić, M. Franulović: MOTIVATION-BASED IDENTITY OF ...

Rahim, A.G., Ignatius, I.U. and Adeoti, O.E. (2012), "Is customer satisfaction an indicator of customer loyalty?", Australian Journal of Business and Management Research, Vol. 2, No. 7, pp. 14-20.

Razović, M. and Tomljenović, R. (2015), "Development model of tourism on Croatian open-sea islands", Tourism: An International Interdisciplinary Journal, Vol. 63, No. 1, pp. 19-36.

Ruiz-Real, J.L., Uribe-Toril, J. and Gázquez-Abad, J.C. (2020), "Destination branding: Opportunities and new challenges", Journal of Destination Marketing \& Management, Vol. 17, pp. 1-13. doi: 10.1016/j.jdmm.2020.100453

Saraniemi, S. (2010), "Destination brand identity development and value system", Tourism Review. Vol. 65, No. 2, pp. 52-60. doi: 10.1108/16605371011061624

Saraniemi, S. and Komppula, R. (2017), "The development of a destination brand identity: a story of stakeholder collaboration", Current Issues in Tourism, Vol. 22, No. 9, pp. 1116-1132. doi:10.1080/13683500.2017.1369496

Tsaur, S.H., Yen, C.H. and Yan, Y.T. (2016), "Destination brand identity: scale development and validation", Asia Pacific Journal of Tourism Research, Vol. 21, No. 12, pp. 1310-1323. doi: 10.1080/10941665.2016.1156003

Wang, X., Zhang, J., Gu, C. and Zhen, F. (2009), "Examining antecedents and consequences of tourist satisfaction: A structural modeling approach", Tsinghua Science and Technology, Vol. 14, No. 3, pp. 397-406. doi: 10.1016/S1007-0214(09)70057-4

Wheeler, F., Frost, W. and Weiler, B. (2011), "Destination brand identity, values, and community: A case study from rural Victoria, Australia", Journal of Travel \& Tourism Marketing, Vol. 28, No. 1, pp. 13-26. doi: 10.1080/10548408.2011.535441

Yoon, Y. and Uysal, M. (2005), "An examination of the effects of motivation and satisfaction on destination loyalty: a structural model", Tourism Management", Vol. 26, No. 1, pp. 45-56. doi: 10.1016/j.tourman.2003.08.016

Yusof, M.F.M. and Ismail, H.N. (2014), "Destination branding identity from the stakeholders' perspectives". International Journal of Built Environment and Sustainability, Vol. 1, No. 1. pp. 71-75. doi: 10.11113/ijbes.v1.n1.58

Zhang, H., Cho, T., Wang, H. and Ge, Q. (2018), "The influence of cross-cultural awareness and tourist experience on authenticity, tourist satisfaction and acculturation in World Cultural Heritage Sites of Korea", Sustainability, Vol. 10, No. 4, pp. 927 . doi: 10.3390/su10040927

Antonia Škravan, MSc Student

University of Rijeka

Faculty of Tourism and Hospitality Management

Primorska 46, P.P. 97, 51410 Opatija, Croatia

antonia.skravan1996@gmail.com

Lorena Bašan, Ph.D., Full Professor

University of Rijeka

Faculty of Tourism and Hospitality Management

Marketing Department

Primorska 46, P.P. 97, 51410 Opatija, Croatia

++385 51 294883; Fax: ++385 51292945

lorenab@fthm.hr

Jelena Kapeš, MSc, Assistant

University of Rijeka

Faculty of Tourism and Hospitality Management

Marketing Department

Primorska 46, P.P. 97, 51410 Opatija, Croatia

++385 51 294759; Fax: ++385 51292945

jelena.kapes@fthm.hr 
ToSEE - Tourism in Southern and Eastern Europe, Vol. 6, pp. 757-773, 2021.

A. Škravan, L. Bašan, J. Kapeš, I. Prižmić, M. Franulović: MOTIVATION-BASED IDENTITY OF ...

\section{Ivana Prižmić, MSc Student}

University of Rijeka

Faculty of Tourism and Hospitality Management

Primorska 46, P.P. 97, 51410 Opatija, Croatia

ivancy.1996@gmail.com

Marino Franulović, BA (Hons) Student

University of Coventry

Faculty of Business and Law

Priority Street Coventry CV1 5FB, Coventry, United Kingdom

franulom@uni.coventry.ac.uk 